\title{
PRIORITIES FOR THE DISTRIBUTION OF INTERBUDGETARY TRANSFERS UNDER THE CONDITIONS OF FISCAL DECENTRALIZATION IN UKRAINE
}

\author{
Yana Sarnetska \\ Department of Finance \\ Kyiv National Economic University named after Vadym Hetman \\ 54/1 Peremogy ave., Kyiv, Ukraine, 03057 \\ ianasarnatska@gmail.com
}

\begin{abstract}
The article is devoted to the problem of the distribution of intergovernmental transfers in Ukraine, taking into account fiscal decentralization trends. To perform the delegated functions, local governments need to have sufficient funding. However, the revenues of local budgets are insufficient to cover all necessary expenses. Therefore, inter-budget transfers, which in Ukraine are the main instrument of financial equalization, play an important role in ensuring the implementation of delegated powers by local governments. The aim of the article is determination of the priorities for the distribution of intergovernmental transfers in Ukraine in the context of fiscal decentralization. The research methodology combines quantitative and qualitative methods. Using quantitative methods, the principles of fiscal decentralization in Ukraine are observed through the mechanism of distribution of intergovernmental transfers. Using high-quality methods and based on the analysis, the priorities of the distribution of inter-budget transfers in the context of fiscal decentralization are formulated. An analysis of foreign publications on fiscal decentralization has shown that the uncertainty of priorities in this area reduces the effectiveness of fiscal decentralization and inhibits the economic development of regions. Prioritization of the distribution of intergovernmental transfers is preceded by the definition of principles for the distribution of intergovernmental transfers. Based on the results of a quantitative analysis, namely, the identified dynamics of fiscal decentralization indicators and the impact of the distribution of intergovernmental transfers on economic development, the following priorities for the distribution of intergovernmental transfers in fiscal decentralization are identified: supporting the prevalence of targeted transfers over non-targeted transfers, increasing the share of capital transfers, increasing the accountability of local authorities self-government regarding the use of funds received in the form of intergovernmental budget transfers.
\end{abstract}

Keywords: intergovernmental transfers, fiscal decentralization, subsidies, subventions, priorities.

DOI: $10.21303 / 2504-5571.2020 .001140$

\section{Introduction}

To perform the delegated functions, local governments need to have sufficient funding. However, the revenues of local budgets are insufficient to cover all necessary expenses. Therefore, inter-budget transfers, which in Ukraine are the main instrument of financial equalization, play an important role in ensuring the implementation of delegated powers by local governments.

As A. Lysenko notes, "the need for inter-budget transfers - additional funds transferred from the state budget to local budgets - arises due to a mismatch between the distribution of powers between management bodies and the distribution of revenue sources for their implementation" [1, p. 3]. That is, the main idea of using financial equalization mechanisms is to reduce the financial unevenness of the regions. However, the current mechanism for the distribution of intergovernmental transfers is characterized by a number of shortcomings and does not fulfill the full equalization function.

This situation is partly due to the imperfection of the formulaic approach to calculating the volume of inter-budget transfers. According to experts of the Institute of Demography and Social Research of the National Academy of Sciences of Ukraine, the mechanical increase in the share of social transfers in the structure of local budget revenues is not proportional to the degree of inequality in society. The imperfect policy of providing social transfers has led to the fact that social payments do not reduce, but rather increase inequality in the distribution of income [2, p. 204]. As noted by N. Kuzmynchuk and A. Zyma, one of the key problems in the field of 
inter-budget transfers is that their distribution has an opaque and unpredictable nature [3, p. 205]. In our opinion, the problems in the distribution of intergovernmental transfers are deeper and pose serious threats to the further development of fiscal decentralization in Ukraine. One of the main problems, in our opinion, is the curvature of the priorities of budget regulation and the lack of receipt of its basic principles.

A large number of works by both domestic and foreign scientists are devoted to the problems of inter-budget transfers. Analyzing the latest publications of foreign scientists, let's came to the conclusion that some economists have proved the positive impact of fiscal decentralization on economic growth, while some believe that the positive impact is limited. So, A. Filippetti and A. Sacchi prove that decentralization itself is not only one of the key factors of economic growth, but also one of the important factors in the development of local self-government [4]. There are publications in which the opposite effect of decentralization falls - slowdown of economic growth, increase in corruption, increase in public debt, etc. [5, 6]. In our opinion, this difference in results is due to the fact that the effect of fiscal decentralization depends on its balance, as well as on the optimality of financial equalization policies.

The negative consequences of fiscal decentralization are primarily associated with the inconsistency of "delegated expenditure powers and responsibilities with resources for performing public functions" [7]. It should be noted that this is one of the most dangerous situations, its consequences can be compared with the effect of a snowball. In the absence of the necessary sources of financing, local governments can't carry out their authority and meet the needs of the local community. As a result, dissatisfaction with local authorities is growing, which can lead to destabilization (political and economic), discrediting local authorities and decentralization itself.

One of the first fundamental studies in the field of fiscal decentralization is the book of W. Oates [8]. This economist has proven that fiscal decentralization has a positive effect on a country's economic growth. However, the degree of positive influence will be different for different countries. An important role in ensuring this positive effect belongs to an effective policy in the field of distribution of budget transfers [9].

The effect of fiscal decentralization depends on the institutional environment [10, p. 93121], the optimal distribution of the tax burden between territories [11], the elasticity of the reaction of capital to the tax burden [12]. As for the influence of the institutional environment, in this case, the role is played not only by the legislative formalization of the activities of local authorities, but also by the willingness of the population to take responsibility for the development of society. In addition, important institutional factors are the level of government accountability, attitudes towards corruption, guarantee of property rights, the rule of law, and the like. If the listed informal institutions are ineffective, then tax competition between territories will not become a factor of economic growth. This is due to the fact that the elasticity of the reaction of factors of economic development (including labor and capital) will be low to changes in tax rates, since the negative impact of informal institutions will dominate.

T. Besley and S. Coate argue that complete decentralization is never optimal [13]. Let's agree with the opinion of these scientists, because, firstly, there are functions of the state (for example, defense, foreign policy, etc.), it makes no sense to transfer to places for objective reasons, so they will always remain centralized. Secondly, the degree of decentralization should take into account the level of development of the territories, the existing infrastructure, that is, the potential of the territories to build up their own tax base and search for other sources of financial resources. Otherwise, the regions will remain dependent on grants from the state budget.

Some economists (D. Albouy [14], H. Blöchliger and O. Petzold [15], T. Büttner, [16], I. Francois [17] argue that fiscal decentralization is a key factor in the country's development. This is due to the fact that under decentralization, funds are spent more rationally, and financing decisions are closer to taxpayers. However, fiscal decentralization is not always effective. An important role is played by the balance of decentralization processes, especially the presence of decentralization in the field of taxation and in the distribution of intergovernmental transfers.

In general, many foreign scientists come to the conclusion that the risks of a decentralization failure are much higher in countries with developing economies. This is, in particular, stated 
in the publication of E. Dabba-Norris and P. Wade [18], which prove that fiscal decentralization in transition economies faces a large number of challenges that are associated not only with the non-optimal distribution of financial resources or powers, but also with a low level of competence of specialists responsible for developing a decentralization strategy and its implementation, a low level of accountability of governments (central and local), weak democratic traditions and the like.

O. Meloni connects the failures of fiscal decentralization with the opportunistic behavior of the electorate [19]. The risks of opportunistic behavior of the electorate are higher in those countries where there is greater dissatisfaction with the policies of the central government. That is, such a phenomenon is not unique to those countries that have just embarked on the path of decentralization. Opportunistic behavior can be either the result of general dissatisfaction with state policy, or the result of the seizure of local political power by elite groups of local politicians, more characteristic of countries with undeveloped democratic traditions.

Also, decentralization failures are associated with the risks of corruption and the ability of the state to reduce its level $[20,21]$. This is due to the fact that the level of corruption is directly related to the openness of the government, that is, if the activities of the government are transparent, characterized by a high level of accountability, then the risk of corruption will be lower. If on the contrary, the government's activities are not transparent, the risk of corruption, and with it the risk of inefficient use of taxpayer funds. Risks of corruption and dissatisfaction of the electorate are growing for the inefficient distribution of intergovernmental transfers [22]. Ineffective redistribution of inter-budget transfers in favor of certain territories in order to obtain loyalty of the electorate leads to the development of a habit of passive consumption. This situation deepens the imbalances in the economic development of the territories and leads to an even greater need for inter-budget transfers.

To summarize the intermediate result, one of the key principles of the distribution of intergovernmental transfers in the conditions of fiscal decentralization in Western countries is the principle of efficiency, the observance of which is based on the principle of transparency and accountability of power [23].

Ukrainian scientists mainly study the principles of the functioning of the budget system, insufficient attention is paid to the principles of budget regulation. So, I. Forkun and T Gordeeva determine the following principles of budget regulation [24 p. 262]: the principle of reality of budget indicators; the principle of the inalienability of the function of territorial regulation in the public administration system; the principle of the need to align regional development; the principle of a clear regulatory mechanism for the system of intergovernmental relations at the state level; targeting principle; principle of social orientation; decentralization principle; responsibility for violation of all principles of budget regulation.

However, in practice such principles are not always respected. Thus, the current procedure for the distribution of intergovernmental transfers does not ensure compliance with the principle of decentralization, which provides for the provision of fiscal freedom to local authorities. The provision of fiscal freedom is often interpreted as the allocation of funds to ensure the exercise of delegated authority. However, this is only one aspect of decentralization. The most important aspect of decentralization is the ability of local governments to independently mobilize the necessary financial resources. As the practice of budget regulation shows, an increase in the volume of subsidized resources leads to a disinterest of local governments in the search for additional sources of budget revenues to finance their own and fixed powers, a decrease in the efficiency of use of the funds received, and, as a consequence, to the low efficiency of the entire system of inter-budget relations [25, p. 123]. Also, in practice, the principle of the reality of budget indicators is not respected, since the planning of revenue and expenditure is based on poor quality financial information. The remaining principles, in our opinion, can't be considered principles in the literal sense of the word, because the principle is the basic foundation of the organization (development) of a certain process. In our opinion, the principle of the inalienability of the function of territorial regulation in the public administration system, the principle of the need for equalizing regional development, the principle of having a clear regulatory mechanism for the system of intergovernmental relations at the state level are in essence tasks, not principles. Thus, in the Ukrainian financial literature 
there is no clear definition of the principles for the distribution of intergovernmental transfers, therefore there are actually no clear priorities for the distribution of intergovernmental transfers in the context of fiscal decentralization. Their justification requires not only a quantitative, but also a qualitative study.

The aim of the article is determination of the priorities for the distribution of intergovernmental transfers in Ukraine in the context of fiscal decentralization.

\section{Methods of research}

The research methodology is based on quantitative methods, the use of which is aimed at assessing the principles of decentralization in terms of the distribution of intergovernmental transfers. For this, from 2008-2018 the following indicators were calculated:

- share of transfers in GDP;

- share of subventions in total transfers;

- share of subsidies in the total volume of transfers;

- volumes of transfers per person and per employee.

In order to evaluate how the distribution system of intergovernmental transfers affects the level of socio-economic development of territories, the influence of the dynamics of intergovernmental transfers on the dynamics of gross regional product (GRP) is analyzed. The gross regional product is chosen as an indicator characterizing the level of socio-economic development of the regions, since it measures the total gross value added created in the region during the study period. Thus, this is a generalized indicator characterizing the dynamics of the economic development of the regions and the growth potential of their financial support.

To conduct the assessment, a regression analysis method is chosen, which allows to identify the relationship between two variables during the study period. GRP per capita, indices of physical growth of GRP and GRP per capita are chosen as the dependent variables. The volumes of intergovernmental transfers per person, the growth rate of intergovernmental transfers per worker and one person are determined as independent variables. The reliability of the constructed regression dependencies is checked using the Fisher criteria and p-value, the standard error value estimation.

Based on the identified trends, using the method of logical generalization, the priorities of the distribution of inter-budget transfers in the conditions of fiscal decentralization are formulated.

\section{Results}

Compliance with the principle of decentralization in terms of the distribution of intergovernmental transfers can be estimated through the dynamics of intergovernmental transfers, their share in GDP, as well as through the share of subventions and subsidies in the total volume of transfers. Fig. 1 shows the share of the total volume of intergovernmental transfers, subsidies and subventions in GDP.

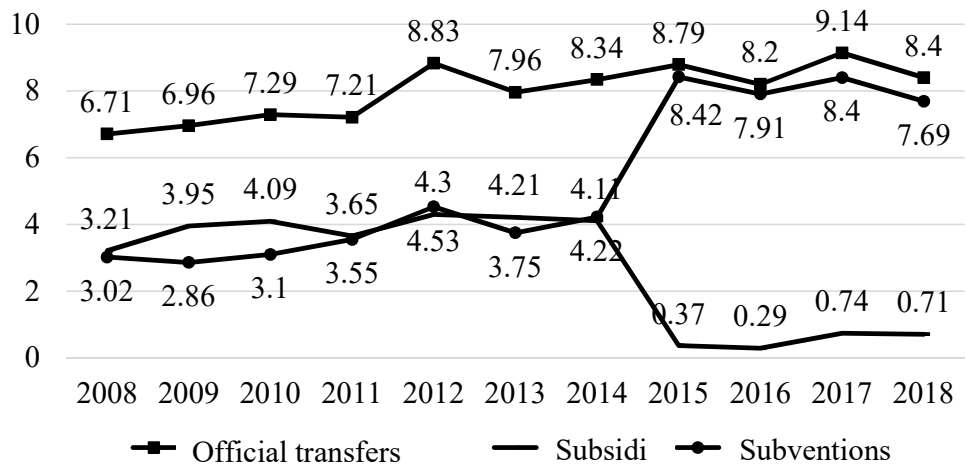

Fig. 1. The shares of inter-budget transfers, grants and subventions in the GDP of Ukraine in 2008-2018, \%. Source: built by the author on the basis of information from the State Treasury Service of Ukraine and the State Statistics Service of Ukraine [26, 27] 
As can be seen from the graphs shown in Fig. 1, the share of official transfers in GDP during 2008-2018 has grown. Although since 2015, reforms have begun to strengthen fiscal decentralization, in 2017 the share of inter-budget transfers in GDP grew to $9.14 \%$, which is the highest value during the study period. In 2018, the share of inter-budget transfers in GDP decreased to $8.4 \%$. The share of subsidies in 2015 fell sharply, during 2015-2018. Its growth is observed from 0.37 to $0.71 \%$. Such dynamics of subsidies is associated with changes in budget legislation that provide for the provision of benefits to targeted financing of local budgets through the provision of subventions. This is what caused the increase in the share of subventions in GDP during 2015-2018.

Fig. 2 shows the dynamics of the share of various types of transfers in the total volumes of inter-budget transfers in Ukraine.

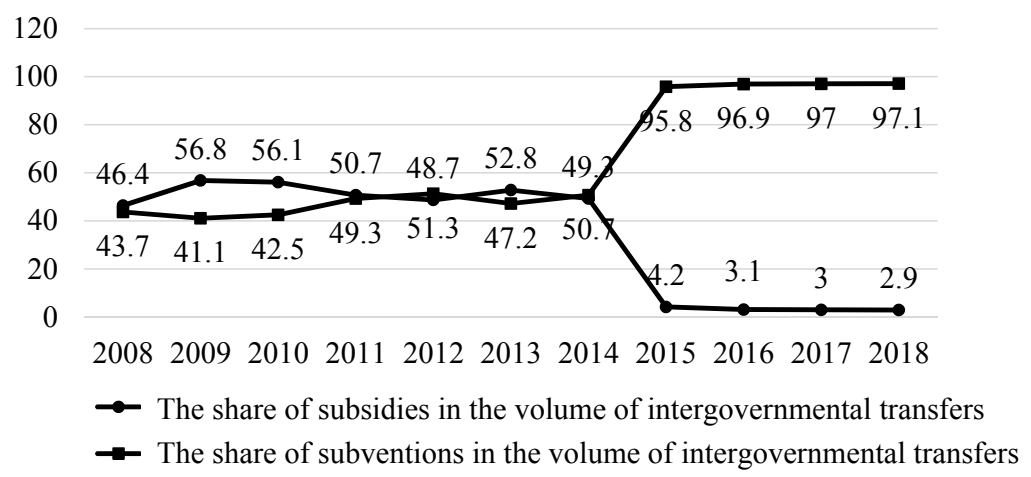

Fig. 2. The shares of subsidies and subventions in the volume of inter-budget transfers in Ukraine in 2008-2018, \%. Source: built by the author based on information from the State Treasury

Service of Ukraine [26, 27]

As can be seen from the graphs presented in Fig. 2, since 2015 the share of subsidies in the volume of inter-budget transfers has sharply decreased. However, such a decrease is not associated with a general reduction in the volume of intergovernmental transfers, just inappropriate grants are replaced by targeted subventions. Such a redistribution of non-targeted transfers in favor of targeted transfers can generally be characterized positively, since it contributes to increased accountability of the authorities. However, to achieve a positive result, it is not enough only to mechanically redistribute inter-budget transfers, an active position of the community residents is required, which required full accountability of the funds at the disposal of local governments. Correct is the observation of V. Pismennyi that "excessive use of subventions may be somewhat discouraged by local governments in increasing the volume of their own revenues and searching for alternative sources of forming the resource base of local budgets" [28, p. 91]. However, most subventions are social in nature, therefore, the state will not be able to sharply reduce their volumes in the near future; for this, it is necessary to change approaches to social support of the population and gradually change the model of the national economy.

It should be noted that with the beginning of reforms in the field of decentralization, the importance of inter-budget transfers has increased due to the specifics of their provision of UTC, because UTC can receive subventions for the development of community infrastructure. At the same time, in order to receive such a subvention, the UTC must comply with the established requirements regarding the borders defined by the long-term plan for the formation of their territories. Despite the fact that most UTC s do not meet these requirements, the process of transition to direct inter-budget relations of UTCs and the state budget is slow.

In general, in order to ensure financial stability in 2016, the budgets of UTC transferred from the state budget 3.5 billion UAH of inter-budget transfers, the basic subsidy is received by 125 communities, and the budgets of 34 communities are financially independent from the state budget, 23 of them are approved with reverse subsidies, 11 budgets are formed without basic and reverse subsidies [29]. Most UTCs received educational subventions and subventions to finance health facilities, but are unable to take the opportunity to receive subventions for 
infrastructure development. If this trend continues, the violation of the principle of decentralization will deepen.

Given the nature and purpose of financial equalization mechanisms, in addition to the principles of decentralization and the reality of budget indicators, it is necessary to highlight the principles of efficiency and accountability. The principle of efficiency involves the use of resources obtained through the mechanism of distribution of intergovernmental transfers, with the maximum positive result. Compliance with the principle of efficiency provides for the targeted use of budget funds, therefore, let's believe that it is not advisable to separate the principle of targeted use of funds. The principle of accountability provides that the processes of formation and use of financial resources of local authorities, including through intergovernmental transfers, should be a shame and understandable for citizens. After all, the existing practice of publishing reports on the execution of local budgets does not ensure this; it is impossible for a layman to understand the published reports on the execution of local budgets. In addition, the information contained in these reports does not have sufficient detail for an ordinary citizen. So, according to published reports it is impossible to trace how much specifically the funds received and used by any organization that is financed from the budget. This does not mean that budget execution reports should be changed, but it is advisable to disclose information on the formation and use of local government financial resources on the websites of local governments, including the volumes of inter-budget transfers.

Evaluating compliance with the principle of effectiveness is challenging. Although efficiency is determined by the maximum effect of using available resources, in practice, this indicator is much more complicated, since it contains qualitative and quantitative components. The quality component is related to the targeted use of funds and accountability of local governments. If to take into account the trend towards an increase in the volume of targeted subventions and a decrease in the volume of subsidies, then there has been progress in terms of compliance with the principle of effectiveness. If to talk about the quantitative component of efficiency, then it is necessary to analyze the quantitative indicators of the provision of intergovernmental transfers, in particular, the volume of transfers per person, one employed, etc., and how their dynamics are related to indicators of economic development in the field.

It should be noted that with the onset of reforms aimed at fiscal decentralization, the volumes of transfers per person and per employee increased (Table 1).

Table 1

Volumes of inter-budget transfers for one person and one working in Ukraine in 2008-2018, UAH.

\begin{tabular}{|c|c|c|c|c|c|c|c|c|c|c|c|}
\hline Indictors & 2008 & 2009 & 2010 & 2011 & 2012 & 2013 & 2014 & 2015 & 2016 & 2017 & 2018 \\
\hline $\begin{array}{l}\text { Volume of intergovernmental } \\
\text { transfers per person }\end{array}$ & 1371 & 1377 & 1545 & 1659 & 2727 & 2543 & 2875 & 4061 & 4579 & 6918 & 7208 \\
\hline Rates of growth, $\%$ & & 100.44 & 112.20 & 107.38 & 164.38 & 93.25 & 113.06 & & 112.76 & 151.08 & 104.19 \\
\hline $\begin{array}{l}\text { Volume of inter-budget } \\
\text { transfers per worker, UAH }\end{array}$ & 3032 & 3146 & 3892 & 4668 & 6115 & 5678 & 7226 & 10581 & 12004 & 14204 & 8568 \\
\hline Rates of growth, $\%$ & $\cdots$ & 103.76 & 123.71 & 119.94 & 131.00 & 92.85 & 127.26 & 146.43 & 113.45 & 118.33 & 130.72 \\
\hline Consumer price index & 122.3 & 112.3 & 109.1 & 104.6 & 99.8 & 100.5 & 124.9 & 143.3 & 112.4 & 113.7 & 109.8 \\
\hline
\end{tabular}

Source: calculated by the author based on information from the State Treasury Service of Ukraine and the State Statistics Service of Ukraine [26, 27]

As can be seen from Table 1, the volume of transfers per person in 2015 is increased by $41.25 \%$, and the volume of transfers per employee - by $46.43 \%$. During 2015-2018 The volume of inter-budget transfers per person is growing on average by more than $12 \%$ per year, and per worker - by $20 \%$ per year. Growth rates since 2010 . Exceed the annual inflation rate, which indicates a real increase in transfers per person and per worker.

Identified trends can't be unambiguously assessed positively or negatively. The assessment depends on what result ensures the use of funds received in the form of intergovernmental transfers. As V. Volokhova notes, "the degree of financial independence of local governments (decen- 
tralization of power) depends on the characteristics of the organization of the system of inter-budgetary relations. The purpose of the relationship is to ensure a guaranteed level of the provision of public goods throughout the country. However, the effectiveness of relations between the links of the budget system is contained not in the level of balancing local budgets due to budget equalization, but in promoting the socio-economic development of territories, as well as increasing the welfare of the population" [30, p. 5].

Fig. 3 shows the dependence of GRP per capita on the volume of inter-budget transfers per person in 2008-2018.

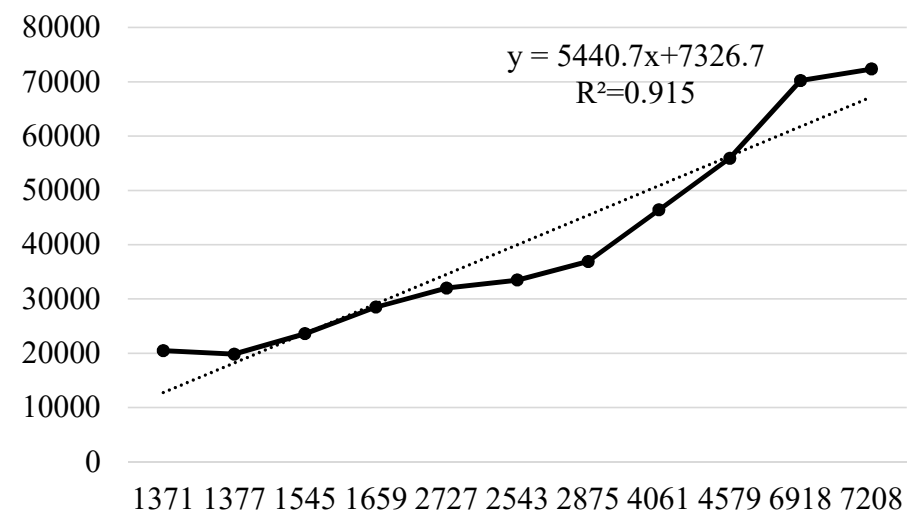

Fig. 3. The dependence of GRP per capita on the volume of

inter-budget transfers per person in Ukraine in 2008-2018. Source: built by the author on the basis of information from the State Treasury Service of Ukraine and the State Statistics Service of Ukraine [26, 27]

As can be seen from the graphs shown in Fig. 3, there is a linear relationship between the studied indicators - GRP per capita and the volume of inter-budget transfers per person. The determination coefficient shows that GRP per person in $91.5 \%$ is determined by the volume of transfers per person. Testing the model for significance using the Fisher criteria and p-value shows that the model, although statistically significant, has a large standard error. That is, for further estimates and for forecasting it can't be used. This result is obtained because the data are not cleared of inflation, and the influence of the time factor is not excluded from the model. Therefore, for further calculations, let's use the relative values, purified from inflation, and without taking into account the time factor.

Fig. 4 reflects the dependence of the index of physical growth of GRP on the volume of inter-budget transfers per person in 2008-2018.

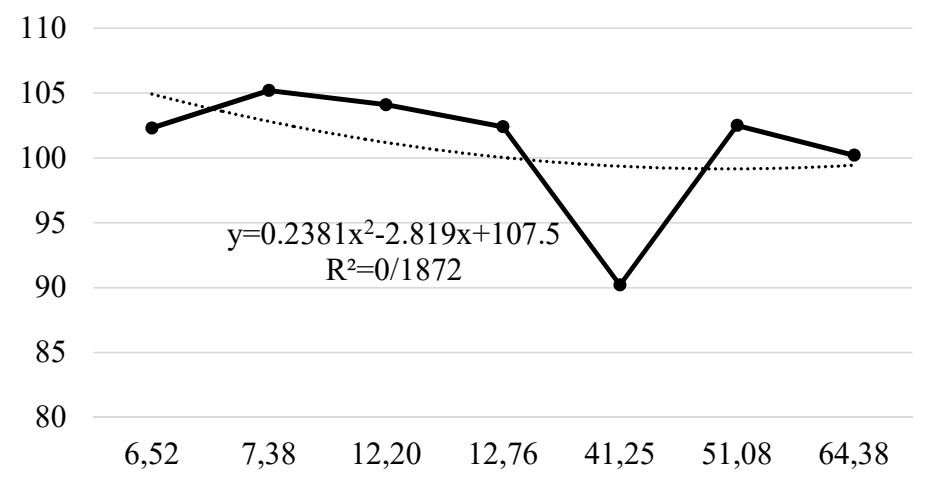

Fig. 4. The dependence of the index of physical growth of GRP on the growth rate of the volume of inter-budget transfers per person in 2008-2018 in Ukraine. Source: built by the author on the basis of information from the State Treasury Service of Ukraine and the State Statistics Service of Ukraine [26, 27] 
As can be seen from the graphs presented in Fig. 4, between the index of physical growth in GRP and the growth rate of intergovernmental transfers per person during 2008-2018 there is a weak second-order regression dependence, since the determination coefficient is only $18.72 \%$. The model is statistically significant, since the calculated value of the Fisher criterion exceeds the table, the standard error is small. The result shows that an increase in inter-budget transfers per person does not have a positive effect on the real growth of GRP. This is partly due to the fact that in the structure of expenditures of local budgets, current expenditures predominate, not capital ones. That is, predominantly passive use occurs, asset investment occurs at a slow pace. In addition, such a result may indicate a low efficiency in the use of funds transferred to local budgets in the form of transfers.

Fig. 5 reflects the dependence of the index of physical growth of GRP on the volume of inter-budget transfers per worker in 2008-2018.

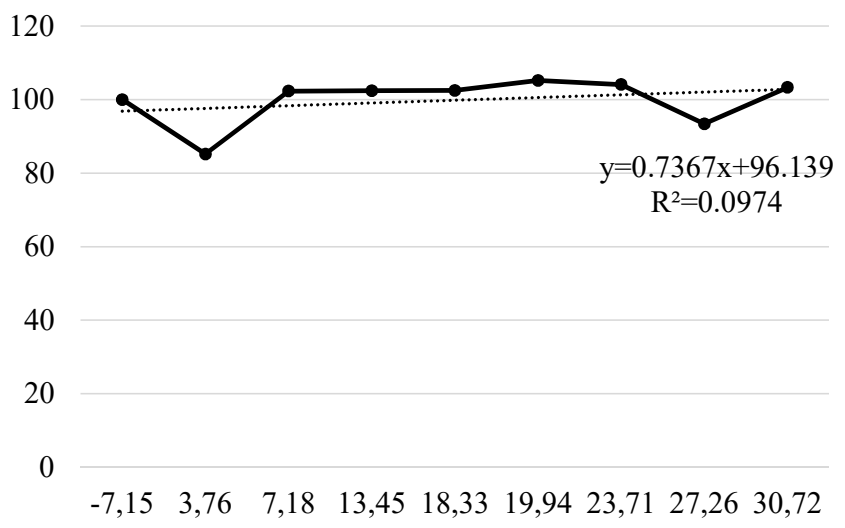

Fig. 5. The dependence of the index of physical growth of GRP on the growth rate of intergovernmental transfers per employee working in 2008-2018.

In Ukraine. Source: built by the author on the basis of information from the State Treasury Service of Ukraine and the State Statistics Service of Ukraine [26, 27]

Graphs presented in Fig. 5 show that the relationship between the studied indicators is very weak, the determination coefficient shows that the index of physical growth in GRP by only $9.74 \%$ is determined by the increase in the volume of inter-budget transfers per worker. Testing the model for statistical significance shows that the relationship is random, the calculated value of the Fisher test is lower than the tabular one. The value of the standard error exceeds the value of the coefficient of elasticity, $\mathrm{p}$-value exceeds 0.5 , which indicates that there is no connection between the studied values. Thus, the dynamics of the growth of interbudgetary relations per person and one worker does not have a positive effect on the physical growth of GRP. In fact, the mechanism for providing intergovernmental transfers does not have a positive effect on the growth of economic welfare of the regions.

Fig. 6 shows the growth rate of GRP per capita from the growth rate of intergovernmental transfers per person.

As can be seen from the graphs shown in Fig. 6, there is a linear relationship between the growth rate of GRP per capita and the growth rate of intergovernmental transfers per person. The determination coefficient shows that the growth rate of GRP per person in $49.79 \%$ is determined by the growth rate of volumes of inter-budget transfers per person. The calculated value of the Fisher coefficient exceeds the table, the standard error is small, which indicates the statistical significance of the model and not the randomness of the relationship between the studied variables. In general, a trend has been revealed that, provided that the funds received in the form of transfers are effectively used, inter-budget transfers can contribute to the growth of economic welfare in the regions. The fact that the determination coefficient is lower than $50 \%$ indicates a significant influence of other factors. 


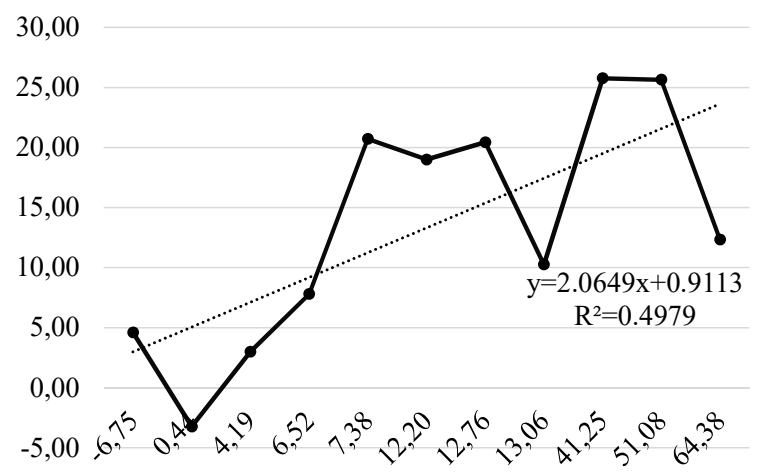

Fig. 6. The dependence of the growth of GRP per capita on the growth rate of the volume of intergovernmental transfers per person in 2008-2018 in Ukraine. Source: built by the author on the basis of information from the State Treasury Service of Ukraine and the State Statistics Service of Ukraine [26, 27]

Fig. 7 shows the growth rate of GRP per capita from the growth rate of the volume of inter-budget transfers per worker.

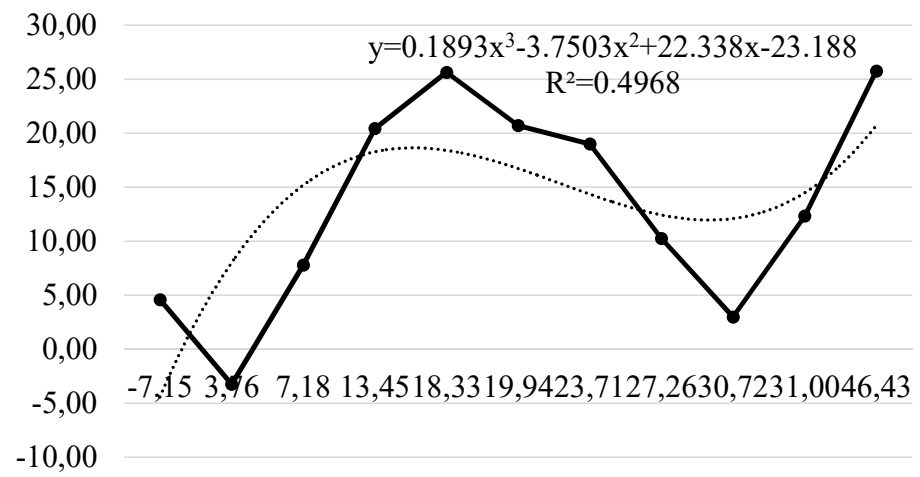

Fig. 7. Dependence of the growth of GRP per capita on the volume of inter-budget transfers per worker in 2008-2018 in Ukraine. Source: built by the author on the basis of information from the

State Treasury Service of Ukraine and the State Statistics Service of Ukraine [26, 27]

As can be seen from the graphs shown in Fig. 7, between the studied indicators there is a polynomial dependence of the third degree with a determination coefficient of $49.68 \%$. Testing the connection for statistical significance showed that the model is insignificant, since the calculated value of the Fisher criterion is less than the table value.

Thus, the results of the analysis of the impact of intergovernmental transfers on the dynamics of GRP do not reveal either a stable negative impact or a stable positive influence. The presence of models that confirmed the existence of a relationship between GRP indicators and the dynamics of inter-budget transfers indicates the presence of potential in the mechanism for providing transfers to positively affect the economic development of regions. Of the identified principles of budget regulation none of the principles is fully observed, which leads to a risk of low efficiency in the use of budget funds, a risk of deepening regional imbalances and a risk of passivity of local governments in mobilizing sources of financing for delegated authority. In such conditions, accordingly, the priorities for the distribution of intergovernmental transfers under fiscal decentralization remain established.

\section{Conclusions}

The research results show that Ukraine has not defined priorities for the distribution of intergovernmental transfers. As analysis of foreign publications on fiscal decentralization shows, the uncertainty of priorities in this area reduces the effectiveness of fiscal decentralization and 
slows down the economic development of regions. Prioritization of the distribution of intergovernmental transfers is preceded by the definition of principles for the distribution of intergovernmental transfers. The results of the analysis of foreign publications show that the basic principles of the distribution of intergovernmental transfers are the principles of efficiency and transparency, non-compliance with which leads to an increase in the risks of corruption and an inhibition of the economic development of the regions. Based on the results of a quantitative analysis, namely, the identified dynamics of fiscal decentralization indicators and the impact of the distribution of intergovernmental transfers on economic development, the following priorities for the distribution of intergovernmental transfers in fiscal decentralization are identified:

- support for the prevalence of targeted transfers over non-targeted transfers, which will contribute to a more efficient use of budget funds;

- increase the share of capital transfers to improve the regional infrastructure. This factor is one of the key to ensuring the economic growth of the regions, and hence the growth of their tax base. In turn, an increase in the tax base will help ensure the financial independence of local governments and reduce the need for intergovernmental transfers;

- increasing the accountability of local governments regarding the use of funds received in the form of intergovernmental transfers.

\section{References}

[1] Lysenko, O. Yu. (2011). Mizhbiudzhetni vidnosyny v Ukraini: osoblyvosti rozvytku ta shliakhy udoskonalennia. Visnyk Natsionalnoi akademii derzhavnoho upravlinnia pry Prezydentovi Ukrainy, 1, 1-8.

[2] Doslidzhennia Instytutu demohrafii ta sotsialnykh doslidzhen NANU. Available at: http://www.idss.org.ua/

[3] Kuzmynchuk, N. V., Zyma, O. H. (2013). Analiz vydiv mizhbiudzhetnykh transfertiv shchodo vyrishennia rehionalnykh problem formuvannia biudzhetiv. Problemy ekonomiky, 4, 198-205.

[4] Filippetti, A., Sacchi, A. (2016). Decentralization and economic growth reconsidered: The role of regional authority. Environment and Planning C: Government and Policy, 34 (8), 1793-1824. doi: http://doi.org/10.1177/0263774x16642230

[5] Martinez-Vazquez, J., Lago-Peñas, S., Sacchi, A. (2016). The impact of fiscal decentralization: a survey. Journal of Economic Surveys, 31 (4), 1095-1129. doi: http://doi.org/10.1111/joes.12182

[6] Baskaran, T. (2009). On the link between fiscal decentralization and public debt in OECD countries. Public Choice, 145 (3-4), 351-378. doi: http://doi.org/10.1007/s11127-009-9570-4

[7] Lelechenko, A. P. (2006). Detsentralizatsiia v systemi derzhavnoho upravlinnia v Ukraini: teoretyko-metodolohichnyi analiz. Kyiv, 20.

[8] Oates Wallace, E. (1972). Fiscal Federalism. New York: Harcourt Brace Jovanovich, 256.

[9] Oates, W. E. (1979). Lump-sum intergovernmental grants have price effects. Fiscal federalism and grants-in-aid. Washington: Urban Institute

[10] Boadway, R. (2001). Inter_Governmental fiscal relations: The facilitator of fiscal decentralization. Constitutional political economy, 12, 93-121. doi: http://doi.org/10.1023/a:1016693903035

[11] Keen, M., Konrad, K. A.; Auerbach, A. J., Chetty, R., Feldstein, M., Saez, E. (Eds.) (2013). The Theory of International Tax Competition and Coordination. Handbook of Public Economics. Vol. 5. Elsevier, 257-328. doi: http://doi.org/10.1016/b978-0444-53759-1.00005-4

[12] Agrawal, D. R., Foremny, D. (2019). Relocation of the Rich: Migration in Response to Top Tax Rate Changes from Spanish Reforms. The Review of Economics and Statistics, 101 (2), 214-232. doi: http://doi.org/10.1162/rest_a_00764

[13] Besley, T., Coate, S. (2003). Centralized versus decentralized provision of local public goods: a political economy approach. Journal of Public Economics, 87 (12), 2611-2637. doi: http://doi.org/10.1016/s0047-2727(02)00141-x

[14] Albouy, D. (2010). Evaluating the Efficiency and Equity of Federal Fiscal Equalization. NBER Working Paper, No. 16144. doi: http://doi.org/10.3386/w16144

[15] Blöchliger, H., Petzold, O. (2009). Taxes or Grants: What Revenue Sources for Sub-central Governments? OECD Economics Department Working Papers, No. 704. Paris.

[16] Buettner, T. (2003). Tax base effects and fiscal externalities of local capital taxation: evidence from a panel of German jurisdictions. Journal of Urban Economics, 54 (1), 110-128. doi: http://doi.org/10.1016/s0094-1190(03)00039-1

[17] Francois, I. (2010). Sub-central Tax Competition: the French Case, presentation to the Workshop on Tax Competition. Bern.

[18] Dabla-Norris, E., Wade, P. (2002). The Challenge of Fiscal Decentralization in Transition Countries. IMF Working Paper WP/02/103. doi: http://doi.org/10.5089/9781451852707.001 
[19] Meloni, O. (2016). Electoral Opportunism and Vertical Fiscal Imbalance. Journal of Applied Economics, 19 (1), $145-167$. doi: http://doi.org/10.1016/s1514-0326(16)30006-x

[20] Oto-Peralías, D., Romero-Ávila, D., Usabiaga, C. (2013). Does fiscal decentralization mitigate the adverse effects of corruption on public deficits? European Journal of Political Economy, 32, 205-231. doi: http://doi.org/10.1016/j.ejpoleco.2013.07.005

[21] World Bank (2012). Anticorruption. Costs and consequences of corruption” World Bank. Washington.

[22] Rodden, J. (2002). The Dilemma of Fiscal Federalism: Grants and Fiscal Performance around the World. American Journal of Political Science, 46 (3), 670-687. doi: http://doi.org/10.2307/3088407

[23] Volden, C. (2007). Intergovernmental Grants: A Formal Model of Interrelated National and Subnational Political Decisions. Publius: The Journal of Federalism, 37 (2), 209-243. doi: http://doi.org/10.1093/publius/pj1022

[24] Forkun, I., Hordieieva, T. (2017). Mizhbiudzhetni vidnosyny ta systema biudzhetnoho rehuliuvannia v Ukraini. Visnyk Khmelnytskoho natsionalnoho universytetu, 5, 261-267.

[25] Kaletnyk, O. V. (2016). Mizhbiudzhetni transferty v umovakh biudzhetnoi detsentralizatsii v Ukraini. Studentskyi Visnyk natsionalnoho universytetu vodnoho hospodarstva ta pryrodokorystuvannia, 1 (6), 122-125.

[26] Derzhavna Kaznacheiska Sluzhba Ukrainy. Available at: https://www.treasury.gov.ua/ua

[27] Derzhavna sluzhba statystyky Ukrainy. Available at: http://www.ukrstat.gov.ua/

[28] Pysmennyi, V. V. (2013). Problemy realizatsii pryntsypiv orhanizatsii mistsevykh finansiv u vitchyznianii praktytsi. Svit finansiv, 1, 87-94.

[29] Zakonodavche zabezpechennia vprovadzhennia reformy mistsevoho samovriaduvannia ta detsentralizatsii vlady: osnovni dosiahnennia ta problemni aspekty. Analitychna zapyska. Available at: http://old2.niss.gov.ua/content/articles/files/ samovriaduv-e4ff2.pdf

[30] Volokhova, I. S. (2010). Mizhbiudzhetni vidnosyny v Ukraini: suchasnyi stan ta perspektyvy rozvytku. Odesa: Atlant, 234.

Received date 18.12.2019

Accepted date 24.01.2020

Published date 31.01.2020
(C) The Author(s) 2020

This is an open access article under the CC BY license (http://creativecommons.org/licenses/by/4.0). 